\title{
Lumpy Jaw in White-Tailed Deer ${ }^{1}$
}

\author{
Juan M. Campos Krauer, Samantha M. Wisely, and Hannah M. Barber ${ }^{2}$
}

\section{What is lumpy jaw?}

Necrobaccilosis, commonly called lumpy jaw, is a deer health problem that all deer farmers eventually face. The disease is considered a significant problem for deer farms in North America, where it is one of the most important production-limiting diseases and can lead to high rates of mortality in fawns (Haigh, Berezowski, and Woodbury 2005; Mainar-Jaime, Woodbury, and Chirino-Trejo 2007). In white-tailed deer, it is usually seen as a disease characterized by swollen jaws or cheeks and necrotic lesions. These swellings consist of tissue masses filled with yellow or greenish pus in and around the jawbone usually at the level of the central molar teeth; hence the name lumpy jaw. The swelling develops slowly and may take months to reach a considerable size, whereupon it discharges small amounts of sticky pus that can contain yellow granules (GavierWiden, Duff, and Meredith 2012).

In white-tailed deer, lumpy jaw is commonly associated with the presence of one or a combination of different anaerobic bacteria species. Among the most commonly identified is Fusobacterium necrophorum, the causative agent of necrobacillosis, followed by Actinomyces bovis and, to a lesser extent, Actinobacillus lignieresii. Trueperella pyogenes (formerly Arcanobacterium pyogenes) can be isolated as a single pathogen or in association with the previously mentioned bacteria (Wobeser, Runge, and Nobel 1975; Mainar-Jaime, Woodbury, and Chirino-Trejo 2007). Among the causal agents of lumpy jaw, Fusobacterium necrophorum and Actinomyces bovis generally affect existing lesions in the face and jawbone. Deer infected with these bacteria suffer mandibular swelling and infected lesions in the dental arcade often become necrotic (Fagan, Oosterhuis, and Benirschke 2005). By comparison, Actinobacillus lignieresii, the causal agent of "woody tongue," also produces mandibular swelling but usually affects only the soft tissues and not the bone (Williams and Barker 2001; Quinn et al. 2011; Gavier-Widen, Duff, and Meredith 2012).

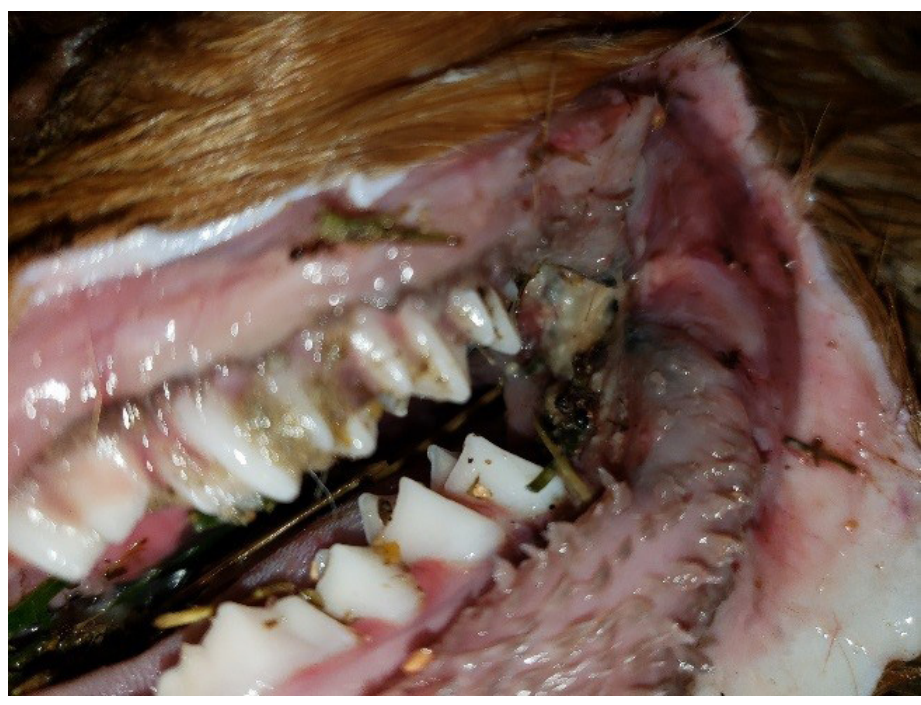

Figure 1. Fawn with tooth and jaw bacterial infection by Trueperella pyogenes.

Credits: Hannah Barber/CVM LACS UF IFAS

1. This document is WEC427, one of a series of the Department of Wildlife Ecology and Conservation, UF/IFAS Extension. Original publication date October 2020. Visit the EDIS website at https://edis.ifas.ufl.edu for the currently supported version of this publication.

2. Juan M. Campos Krauer, assistant professor, Department of Large Animal Clinical Sciences, UF College of Veterinary Medicine; Samantha M. Wisely, professor, Department of Wildlife Ecology and Conservation; and Hannah M. Barber, graduate research assistant, Department of Large Animal Clinical Sciences, UF College of Veterinary Medicine; and UF/IFAS Extension, Gainesville, FL 32611.

The Institute of Food and Agricultural Sciences (IFAS) is an Equal Opportunity Institution authorized to provide research, educational information and other services

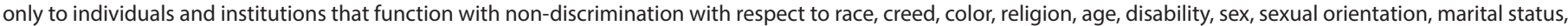

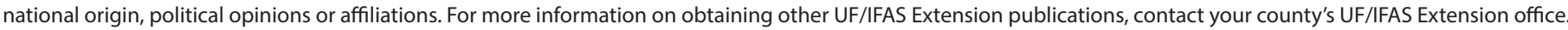
U.S. Department of Agriculture, UF/IFAS Extension Service, University of Florida, IFAS, Florida A \& M University Cooperative Extension Program, and Boards of County Commissioners Cooperating. Nick T. Place, dean for UF/IFAS Extension. 


\section{How do deer get lumpy jaw?}

Lumpy jaw begins when a deer gets a cut or a puncture in the lining of its mouth, and the wound becomes infected with one of the causal bacteria (Gavier-Widen, Duff, and Meredith 2012). Small wounds can be produced by the impact of coarse feed between teeth, when a fawn's teeth break through its gums during development, or when its permanent teeth come in after it loses its baby teeth (Gyles et al. 2010). Fusobacteria and other oral (anaerobic) bacteria may then easily penetrate and colonize the wound, starting the necrotizing infection that forms hard abscesses and the pus that characterizes lumpy jaw (Wobeser, Runge, and Nobel 1975; Roeder et al. 1989).

The same bacteria that cause lumpy jaw can cause abscesses in other organs and parts of the body besides the jaw. These infections are quite dangerous because they can lead to sepsis, which is nearly always lethal. The general name for the syndromes caused by these bacteria is "necrobacillosis," but there are other names as well, usually referencing the part of the body affected by the bacteria. Necrotic stomatitis affects the mouth, hepatic necrobacillosis affects the liver, and foot rot affects the deer's feet. All are syndromes caused by the same organisms that cause lumpy jaw (Gyles et al. 2010). Although confirmation of necrobacillosis can only be performed through proper laboratory identification of the causative agents, in white-tailed deer the presence of lumpy jaw is highly suggestive of this disease (MainarJaime, Woodbury, and Chirino-Trejo 2007).

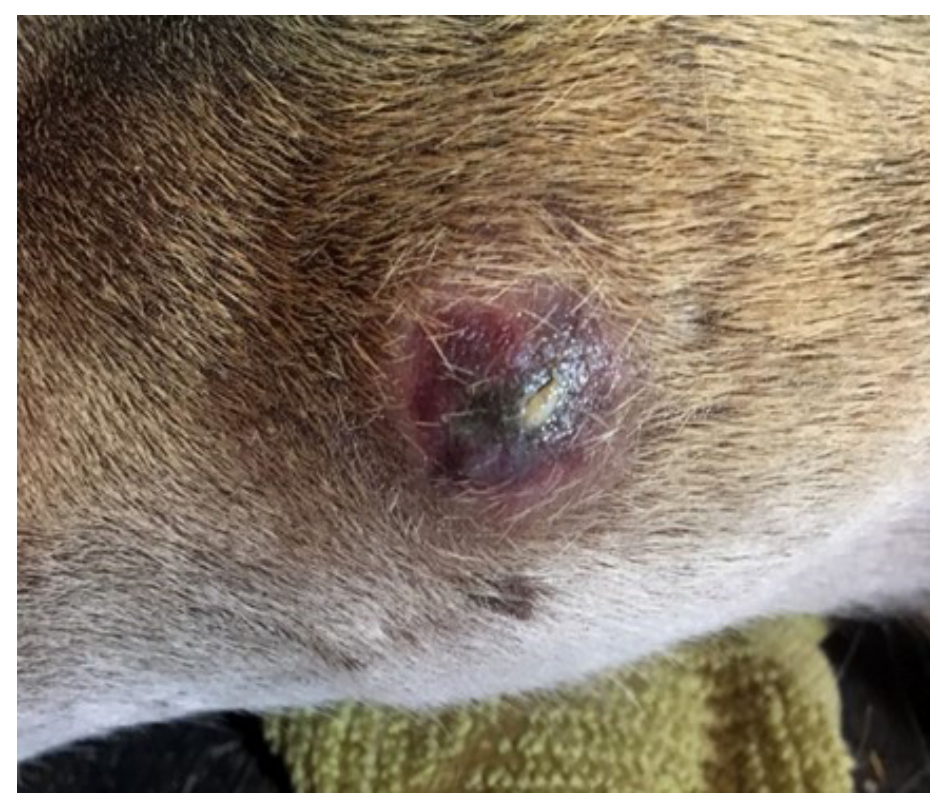

Figure 2. External view of an abscess on the lower jaw of a 5-monthold fawn.

Credits: Hannah Barber/CVM LACS UF/IFAS
Because Fusobacterium and Trueperella bacteria are commonly found as part of the normal intestinal flora of deer (Delgado et al. 2017), it is not clear what triggers the occurrence of the disease or disease outbreaks on deer farms. Most of the research on the pathogenesis of necrobacillosis has been carried out on domesticated ruminants, where a similar syndrome is seen. In deer, many risk factors can increase the prevalence of the disease. Stress from inappropriate or overly frequent animal handling, overcrowding, and social instability are important, as is poor sanitation resulting from fecal contamination of facilities and feeding equipment (Wobeser, Runge, and Nobel 1975; Hattell et al. 2004; Mainar-Jaime, Woodbury, and Chirino-Trejo 2007). Similarly, geographical and environmental conditions also influence the occurrence of lumpy jaw; the agent can survive longer in cold, muddy conditions and in humid soil that has a high manure content (Mainar-Jaime, Woodbury, and Chirino-Trejo 2007).

\section{What are the signs of lumpy jaw you need to look for?}

- Problems eating (losing weight), drooling, a notably dry coat, separating from the herd

- Any swelling of the lower jaw or surrounding tissue

- Continued swelling and development of lesions containing thick, yellow-green pus (abscesses)

\section{How do I treat lumpy jaw?}

The treatment of lumpy jaw focuses on killing the bacteria and stopping the spread of the lesion. However, the hard mass will usually not retreat significantly once it has had time to be established, making it extremely important to detect and treat cases as soon as possible (Fagan, Oosterhuis, and Benirschke 2005). Effective results can be obtained with concurrent administration of antimicrobials, including penicillin, florfenicol, or oxytetracycline (Chirino-Trejo, Woodbury, and Huang 2003). However, unsuccessful treatments are also common, generally not because the bacterium was resistant to the antimicrobial drug but because the lesions are abscesses, which have a protective membrane that prevents the antimicrobials from directly contacting the bacteria (Chirino-Trejo, Woodbury, and Huang 2003). If possible, abscesses should be drained and flushed with iodine and antimicrobials to remove toxins and pus. On occasion, surgery to debride large mandibular lesions combined with strong antimicrobial therapy may be needed (Fagan, Oosterhuis, and Benirschke 2005). Most drugs used for the treatment of lumpy jaw are not currently licensed for use in deer. Do not use antibiotics without asking your local veterinarian for the best treatment option. 


\section{How can I prevent lumpy jaw in my}

\section{farm?}

Prevention by vaccination with commercial bacterins made for cattle or sheep or autogenous bacterins has been attempted, but efficacy has not been proven (Mainar-Jaime, Woodbury, and Chirino-Trejo 2007). The best strategy to prevent the occurrence is to observe good general hygiene practices such as avoiding the build-up of fecal contamination in pens and using different equipment for handling manure and feeding animals. Feeding and drinking areas and working facilities should be cleaned and disinfected to prevent spread of the organisms that cause lumpy jaw. Remove any foreign objects that deer could chew on to reduce the risk of their getting cuts or punctures. Implement a management program that reduces stressful situations. Avoid overcrowding and overhandling; do not mix deer of different ages or sexes; and be aware of social hierarchies in pens. Dominant bucks can be very aggressive to younger or subordinate bucks; the same happens among does and fawns. This can increase stress in the animal, which can increase the likelihood of a bacterial infection.

Soil contamination is an important route of infection. Affected animals should be isolated from healthy animals. Any secretion or pus from the lesion should be collected and incinerated and not allowed to contaminate the pen. The type of soil in your pen can play a role in the persistence and transmission of disease-causing bacteria like $F$. necrophorum and Trueperella. Remove wet, muddy soil that has a high manure content and replace with limestone, particularly in areas near food and water troughs that tend to remain humid for a long time. Finally, in rare occasions, F. necrophorum can be passed to humans from handling animals with open sores or pus (Finegold and George 1989). Always wash equipment, your hands, and any exposed areas of your body with soap and disinfectant after working with sick animals.

Lumpy jaw is a common disease in white-tailed deer farms throughout North America. With effective management, good hygiene practices, early detection, and appropriate treatment, it is possible to prevent or reduce major economic losses.

For more information about deer health, please visit the UF/IFAS Cervidae Health Research Initiative at https://wec. ifas.ufl.edu/cheri/.

\section{References}

Chirino-Trejo, M., M. R. Woodbury, and F. Huang. 2003. "Antibiotic sensitivity and biochemical characterization of Fusobacterium spp. and Arcanobacterium pyogenes isolated from farmed white-tailed deer (Odocoileus virginianus) with necrobacillosis." Journal of Zoo and Wildlife Medicine 34(3): 262-268. https://doi.org/10.1638/02-019

Delgado, M. L., P. Singh, J. F. Funk, J. A. Moore, E. M. Cannell, J. Kanesfsky, S. D. Manning, and K. T. Scribner. 2017. "Intestinal microbial community dynamics of whitetailed deer (Odocoileus virginianus) in an agroecosystem." Microb Ecol 74(2): 496-506. https://doi.org/10.1007/ s00248-017-0961-7

Fagan, D. A., J. E. Oosterhuis, and K. Benirschke. 2005. "'Lumpy jaw' in exotic hoof stock: A histopathologic interpretation with a treatment proposal." Journal of Zoo and Wildlife Medicine 36: 36-43. https://doi.org/10.1638/03-056

Finegold, S. M., and W. L. George. 1989. Anaerobic Infections in Humans. San Diego, CA. Academic Press, Inc. https://doi.org/10.1016/B978-0-12-256745-2.50043-X

Gavier-Widen, D., J. P. Duff, and A. Meredith. 2012. "Other bacterial infections." In: Infectious Diseases of Wild Mammals and Birds in Europe. Oxford, UK: John Wiley \& Sons, LTD. 428-449. https://doi.org/10.1002/9781118342442. ch37

Gyles, C. L., J. F. Prescott, J. G. Songer, and C. O. Thoen. 2010. "Fusobacterium." In: Pathogenesis of Bacterial Infections in Animals. 4th Edition. Ames, Iowa: John Wiley \& Sons, LTD. 514-516. https://doi. org/10.1002/9780470958209

Haigh, J. C., J. Berezowski, and M. R. Woodbury. 2005. "A cross-sectional study of the causes of morbidity and mortality in farmed white-tailed deer." Canadian Veterinary Journal 46: 507-12.

Hattell, A. L., D. P. Shaw, B. C. Love, D. C. Wagner, T. R. Drake, and J. W. Brooks. 2004. "A retrospective study of mortality in Pennsylvania captive white-tailed deer (Odocoileus virginianus): 2000-2003." J Vet Diagn Invest 16: 515-521. https://doi.org/10.1177/104063870401600605

Mainar-Jaime, R.C., M. R. Woodbury, and M. Chirino-Trejo. 2007. 'Survey on 'lumpy jaw' on deer farms in western Canada: Prevalence and distribution, and identification of associated factors." New Zealand Veterinary Journal 55(1): 30-39. https://doi.org/10.1080/00480169.2007.36732 
Quinn, P. J., B. K. Markey, F. C. Leonard, E. S. Fitzpatrick, S. Fenning, and P. J. Hartigan. 2011. "Actinobacteria." In: Veterinary Microbiology and Microbial Disease. 2nd Edition. Oxford, UK: Wiley-Blackwell John Wiley \& Sons, Inc.

196-206.

Roeder, B. L., M. M. Chengappa, K. F. Lechtenberg, T. G. Nagaraja, and G. A.Varga. 1998. "Fusobacterium necrophorum and Actinomyces pyogenes associated facial and mandibular abscesses in blue duiker." Journal of Wildlife Diseases 25: 370-7. https://doi.org/10.7589/0090-3558-25.3.370

Williams, E. S., and I. K. Barker. 2001. "Mycobacterium bovis infection in deer." In: Infectious Diseases of Wild Mammals 3rd Edition. Ames, Iowa: Blackwell Publishing Company. 350-353. https://doi.org/10.1002/9780470344880

Wobeser, G., W. Runge, and D. Nobel. 1975. "Necrobacillosis in deer and pronghorn antelope in Saskatchewan." Canadian Veterinary Journal. 16: 3-9. 